\title{
Analisis Kritis Pembiayaan Murābaḥah Dan Mekanisme Pricing Di Keuangan Islam Modern Indonesia
}

\author{
Ahmad Maulidizen \\ Program Doktor Ekonomi Islam, Akademi Pengajian Islam \\ Universiti Malaya, 50603, Kuala Lumpur, Malayasia \\ *Email korenpondensi: ahmadzen682@gmail.com
}

Recieved 16-04-2018 | Revised 07-06-2018 | Accepted 23-06-2018

\begin{abstract}
Islamic banking in Indonesia has experienced significant growth, including assets, financing provided and the number of customers. In 2012-2017 Sharia bank financing 70-80\% is given to the community by using the contract of murābahah, in the form of consumptive and productive. The activities of sharia banks should be guided by the National Sharia Council Fatwa in performing its functions optimally and implementing the Shari'a comprehensively. While murābahah financing is still reaping a variety of criticism from Islamic finance experts because there are provisions that are not in accordance with fiqh muamalat and also need to find solutions how to calculate the price and mark up allowed so that customers do not burden at a cost much more expensive than the interest applied in conventional banks. This is so that Sharia banks can compete with other banks. Therefore, this article will explain concept concept of murābahah conceptually and application in Bank Islam in Indonesia. The purpose of writing this article so that the implementation of the contract muräbahah in Bank Syariah in Indonesia can be in accordance with the principles of sharia that put forward the principle of justice and no party is harmed.
\end{abstract}

Keywords: Murābahah Financing, Modern Islamic Financing, Indonesia.

\section{Abstrak}

Perbankan syariah di Indonesia telah mengalami pertumbuhan yang signifikan, termasuk aset, pembiayaan yang diberikan dan jumlah pelanggan. Pada tahun 2012-2017 Pembiayaan bank Syariah 70-80\% diberikan kepada masyarakat dengan menggunakan kontrak murābahah, dalam bentuk konsumtif dan produktif. Kegiatan bank syariah harus berpedoman kepada Fatwa Dewan Syariah Nasional dalam menjalankan fungsi secara optimal dan menjalankan syariat secara komprehensif. Sedangkan pembiayaan murabahah ini masih menuai berbagai kritik dari pakar keuangan Islam dikarenakan terdapat ketentuan yang tidak sesuai dengan figh muamalat dan juga perlu dicari solusi cara menghitung harga dan mark up yang diperbolehkan sehingga nasabah tidak bebankan dengan biaya yang jauh lebih mahal dibandingkan dengan bunga yang diterapkan di bank konvensional. Hal ini agar bank Syariah dapat bersaing dengan bank lainnya. Oleh karena itu, artikel ini akan menjelaskan tentang konsep murābahah secara konseptual dan aplikasi di Bank Islam di Indonesia. Tujuan penulisan artikel ini agar pelaksanaan kontrak Murābahah di Bank Syariah di Indonesia dapat sesuai dengan prinsip syariah yang mengedepankan asas keadilan dan tidak ada pihak yang dirugikan.

Kata kunci: Pembiayaan Murābahah Keuangan Islam Modern, Indonesia

Saran sitasi: Maulidizen, A. (2018). Analisis Kritis Pembiayaan Murābaḥah di Keuangan Islam Modern Indonesia. Jurnal Ilmiah Ekonomi Islam, 4(2), 76-90. doi:http://dx.doi.org/10.29040/jiei.v4i2.189

DOI: http://dx.doi.org/10.29040/jiei.v4i2.189 


\section{Pendahuluan}

Syariah Islam merupakan jalan hidup umat manusia dan diciptakan untuk mengantarkan manusia menuju kebahagiaan di dunia dan akhirat (falāh) melalui penegakan berbagai seruan yang terkandung dalam al-Quran dan al-Hadīth. Aturan tersebut mengatur kehidupan manusia dalam berbagai aspek, yaitu bidang 'ubūdiyah dan mu'āmalah (Nasution, 1986, Maulidizen, 2018). Selain prinsip-prinsip ekonomi Syariah sebagaimana disebutkan di atas, dalam Hukum Islam mempunyai juga moral ekonomi, yang dikenal dengan "Golden Five", yaitu keadilan, kebebasan, persamaan, partisipasi, dan pertanggungjawaban. Golden Five ini dijadikan sebagai prinsip-prinsip umum yang mendasari prinsip ekonomi Syariah (Tabari, 2010). Seperti halnya Bank Konvesnional, Bank Syariah berfungsi juga sebagai institusi perantara, yaitu berfungsi menghimpun dana dari masyarakat dan menyalurkan kembali dana tersebut kepada masyarakat yang memerlukan dalam bentuk pembiayaan (Muhammad, 2005). Falsafah pembiayaan Bank Syariah pelaksanaannya harus memenuhi aspek syariah dan aspek ekonomi (Saed, 2008; Maulidizen, 2017).

Pembiayaan yang paling dominan dilakukan oleh Bank Syariah saat ini adalah murābaḥah. Hal ini dapat dibuktikan dari beberapa hasil penelitian, ternyata Bank Syariah pada umumnya banyak menerapkan pembiayaan murabahah sebagai pembiayaan yang utama yaitu $85 \%$. Sejak awal tahun 1984, di Pakistan pembiayaan murābahah mencapai sekitar $87 \%$. Sementara di Dubai Islamic Bank, pembiayaan murabahah mencapai sekitar 82\%. Bahkan di Islamic Development Bank (IDB), selama lebih dari sepuluh tahun periode pembiayaan $73 \%$ dari total pembiayaanya adalah pembiayaan murabahah. Padahal, sebenarnyaBank Syariah memiliki produk unggulan yang berbasis profit and loss sharing (PLS), yaitu mudarabah dan musharakah.

Meskipun demikian, mekanisme pembiayaan murabahah ini, ternyata tidak lepas dari kritikan para Ilmuwan Muslim. Mereka berpen- dapat bahwa Bank Syariah dalam melaksanakan kegiatan usahanya, ternyata buka menghilangkan bunga dan membagi risiko, tetapi tetap mempertahankan praktek pembebanan bunga dengan label 'Islam'. Di kalangan ulama fikih pun, keabsahan pembiayaan murabahah masih terdapat perdebatan. Ada sebagian ulama yang membolehkan karena murabahah merupakan jual beli, tetapi sebagian ulama yang melarang karena beranggapan bahwa murabahah itu bukanlah jual beli melainkan hilah untuk mendapatkan riba. Ada sebagian ulama yang menganggap sebagai ba'i al-inah yang haram hukumnya, dan ada pula yang menganggapnya sebagai ba 'atani fi ba 'iah (Qaraḍāwī, 1987).

Berdasarkan dari permasalahan di atas, maka maksud dan tujuan dari penulisan artikel ini adalah untuk menjelaskan konsep murābahah dalam perspektif fiqh, murabahah dalam lembaga keuangan Islam modern, kritik terhadap pelaksanaan murabahah serta menawarkan konsep pricing dalam produk murabahah di lembaga keuangan Islam Modern sebagai solusi alternatif dalam memperbaiki kesalahan yang ada. Artikel ini termasuk ke dalam kajian perpustakaan (library research), untuk memperoleh serta mengumpul bahan-bahan rujukan dalam bentuk dokumentasi yang berkaitan dengan judul yang diangkat dalam penulisan, kemudian disajikan dengan metode desktiptif kualitatif. Penelitian ini dilakukan untuk mengetahui bagaimana aplikasi pembiayaan murābaḥah dan mekanisme perhitungan harga jual yang dapat dilakukan sehingga dapat bersaing dengan bank lainnya.

\section{Metode Penelitian}

Penelitian ini merupakan penelitian kepustakaan (library research) dengan pendekatan deskriptif. Yaitu dengan mendeskripsikan atau menjelaskan analisis kritik pembiayaan murabahah di lembaga keuangan Islam modern dan menawarkan suatu konsep dalam menentukan harga atau margin sebagai keuntungan. Metode pengumpulan data pada penelitian ini menggunakan dokumentasi, dan berbagai artikel 
dan buku. Kemudian dianalisis menggunakan content analysis (analisis isi), yaitu dengan menganalisa data-data kepustakaan yang bersifat deskriptif atau analisis ilmiah tentang pesan suatu premis. Metode analisis data secara deduktif, induktif dan komparatif.

\section{Hasil dan Pembahasan}

\subsection{Pengertian Murabahah}

Perkataan murābahah berasal dari kata kerja bahasa Arab rābaha, yurābihu, murābahatan. Kata kerja asalnya adalah dari fi 'il thulāthi iaitu rabaha. Dalam kamus Lisān al-Arabī, perkataan al-ribhu, al-rabaḥu dan al-rabbaḥu membawa maksud yang sama yaitu pertambahan atau pertumbuhan dalam perniagaan (Ibn Manzūur, 1954; Fīyrūzābādī, 1983). Sedangkan Ibn al'Arabī menyatakan perkataan al-ribhu dan alrabahu bermakna keuntungan dalam perniagaan. Kombinasi takrifan tersebut membawa kepada pengertian al-ribh sebagai keuntungan dari perputaran modal yang dihasilkan melalui pekerjaan, perdagangan dan berbagai transaksi yang dilakukan secara individu maupun kolektif (Maulidizen, 2017). Sedangkan murābahah adalah kata yang berasal dari kata kerja rābaḥa yang bermaksud saling memberi keuntungan antara pembeli dan penjual. Walau bagaimanapun, jika dilihat dari aspek komersial, hanya memberi keuntungan pihak penjual dan pembeli saja, tetapi dari aspek yang lain, tetap memberi keuntungan kepada pembeli yaitu dalam bentuk tercapai hajatnya untuk memperoleh dan memiliki sesuatu barang (Kamri dan Mansor, 2002).

Murābahah diharuskan menjadi salah satu intrumen pembiayaan berdasarkan al-Qur'ān dan al-Ḥadīth maupun ijmak (al-Kāsān̄i, t.t). Akan tetapi, tidak didapati ayat al-Qur'ān dan alHadīth Nabi Muhammad SAW yang secara langsung berkenaan dengan murābahah, hanya didapati pedoman secara umum tentang jual beli, keuntungan, kerugian dan perniagaan (Borhan, 1998; Saed, 1996). Para 'ulama mendefinisikan murābahah dengan berbagai bentuk definisi tetapi dengan maksud yang relatif sama. Menurut Ibn al-Ḥumām, murābahah adalah suatu akad penyerahan barang perniagaan yang dimiliki oleh seseorang, berdasarkan biaya harga asal pada akad yang pertama, serta menambah keuntungan, dengan memberitahukannya kepada pembeli (Ibn Humām, 1970). Keuntungan yang setujui boleh ditentukan dalam bentuk jumlah uang tertentu atau dalam bentuk persentase tertentu daripada nisbah harga pembeliannya, misalnya $10 \%$ atau 20\% (al-Sharbīnī, 1958; Musjtari, 2000; Muhammad, 2000).

Ibn Qudāmah memberikan definisi sebagai suatu bentuk perniagaan yang menjual suatu barang dengan harga modal serta menambah keuntungan yang diketahui (Ibn Qudāmah, 1972; al-Dasūqīi, t.t). Al-Imām Māik turut menjelaskan bahwa murābahah yaitu apabila ia menjual sesuatu dengan mengambil keuntungan satu dirham bagi setiap dirham modal yang dikeluarkannya atau setengah dirham bagi setiap dirham yang dikeluarkannya, atau sebelas dirham bagi setiap sepuluh dirham modal yang dikeluarkannya, dari segi untungnya sedikit dari modal atau untungnya lebih banyak daripada modal, bergantung kepada persetujuan kedua belah pihak (al-Tanūkhi, t.t). Al-Imām Mālik mendasarkan keabsahan murābahah dengan 'amalu ahli al-Madīnah "Ada konsensus pendapat di sini (Madinah) mengenai hukum orang yang membeli baju di sebuah kota, dan mengembalikannya ke kota lain untuk menjualnya berdasarkan suatu kesepakatan terhadap keuntungan" (Maulidizen, 2018). Al-Imām al-Shāfi'‘̄ menerima keabsahan murābaḥah. Beliau menyatakan: "Jika seseorang menunjukkan komoditas kepada seseorang dan mengatakan, "Kamu beli untukku, aku akan memberimu keuntungan begini, begini", kemudian orang itu membelinya, maka transaksi itu sah” (Al-Shāfi‘̄i, 1968). Al-Imām al-Nawawī, salah satu tokoh dalam mazhab Shāfi ‘'̄ menyatakan murābahah sah menurut hukum tanpa ada bantahan (al-Nawawī, t.t). Ibn Rushd mendefinisikan murābahah sebagai jual beli barang pada harga modal dengan tambahan keuntungan yang disepakati (Ibn Rushd, 1988). Ulama' Hanafì membenarkannya berdasarkan kondisi penting bagi keabsahan penjualan di 
dalamnya, dan juga kerana manusia memerlukannya (Saed, 2008). Dengan demikian murābahah merupakan penjualan barang pada harga tertentu yang meliputi harga beli dan margin keuntungan dan seharusnya harga tersebut disepakati oleh kedua belah pihak yang berkontrak (Usmani, 2002). Dengan menggunakan kaedah murābahah, pemilik barang (pihak bank) membuat perjanjian jual beli dengan nasabah. Dalam hal ini nasabah sebagai rekan perkongsian memohon dari pihak bank untuk membeli suatu aset untuknya. Pihak bank akan membeli aset yang dikehendaki dan akan menjual kepada nasabah dengan suatu tingkat harga yang meliputi biaya awal beserta tambahan untung sesuai persetujuan kedua belah pihak (Sholihuddin, 2011; Sutedi, 2009). Nasabah juga akan membayar secara ansuran mengikut tempo waktu tertentu yang disetujui bersama tanpa adanya bunga yang dikenakan ke atas hutang tersebut.

Oleh karena demikian, dapat difahami bahwa mekanisme murābahah yang berlaku sekarang adalah merupakan skema perniagaan barang antara kedua belah pihak berdasarkan persetujuan pada harga yang merangkumi harga barang dan keuntungan. Nasabah meminta pembiayaan, kepada bank, institusi keuangan atau koperasi untuk membeli aset yang dikehendaki dan memesan barang tersebut dengan harga asal dicampur dengan keuntungan yang diberitahukan kepada nasabah (al-Ashqar, et al., 1998; Haron, 1996). Pada asasnya murābahah mempunyai unsur pinjaman kemudian digantikan kepada konsep jual beli barang, di mana pembiaya akan memberitahu biaya pemesanan barang dan keuntungan yang diambil dari nasabah. Maka atas dasar harga yang ditambah dengan keuntungan tersebut menjadi harga jual yang ditawarkan kepada nasabah sebagai pembeli yang akan membayar secara tangguh, beransur-ansur atau sekaligus mengikuti persetujuan kedua belah pihak (Hamoud, 1985). Jadi dapat kita simpulkan bahawa, murābahah adalah akad jual beli barang dengan menyatakan harga perolehan dan keuntungan (margin) yang disepakati antara penjual dan pembeli (Karim, 2004). Sedangkan yang dimaksud harga dalam jual beli murābahah adalah harga beli dan biaya yang diperlukan ditambah keuntungan sesuai dengan hasil kesepakatan (Burhanuddin, 2010).

\subsection{Rukun dan Syarat Kontrak Murābahah}

Melihat murābahah merupakan salah satu dari jenis kontrak jual beli yang dihalalkan, maka syarat dan rukun kontrak murābahah harus memenuhi syarat-syarat dan rukun jual beli secara umumnya, yaitu 1) Dua orang yang berakad (penjual dan pembeli) /al- 'āqidāni, 2) Sighah akad (ijab dan kabul) / șighah, 3) Barang dan harga /ma'qūd 'alayh dan al-thaman. Di samping itu terdapat beberapa syarat-syarat khusus baginya, yaitu 1) Penjual hendaklah menyatakan biaya atau modal sebenarnya barang yang hendak dijual kepada pembeli, 2) Penjual dan pembeli menyepakati besarnya keuntungan yang ditetapkan sebagai tambahan kepada modal, yang mana jumlah kedua-duanya merupakan harga jual bagi akad murābahah tersebut, 3) Sekiranya terjadi kesalahan dalam menentukan besaran sesungguhnya biaya atau modal barang itu, pihak pembeli boleh membatalkan kontrak tersebut, 4) Barang dan harga bukanlah dari barang ribawi yang sedang terjadi pertukaran jual belinya kecuali mematuhi syarat-syarat pertukaran barang ribāwi, 5) Sekiranya barang yang hendak dijual secara murābahah itu sudah dibeli dari produsen, jual beli pertama ini harus sah menurut syarak (Usmani, 2002; Ibn Qudāmah, 1972; al-Kāsānī, t.t; Wạ̣bah, 1989).

Dengan adanya lima persyaratan tersebut di atas akan memberikan jaminan sahnya kontrak dan terhindar dari amalan ribā (Hasanīn, 1992). Para Fuqaha menggolongkan murābahah dalam kategori jenis kontrak buy"̄' al-amānah lantaran disyaratkan supaya penjual ketika melakukan kontrak ini terlebih dahulu menyatakan harga perolehan barang yang dibelinya itu sebelum menentukan harga jual (Shubair, 1998; al-Zarqā, 1968). Jika didapati bahwa informasi mengenai harga perolehan tidak betul, maka pembeli berhak membuat pilihan (khiyār) untuk membatalkan atau meneruskannya (Ibn 
Qudāmah, 1972). Khiyār itu memiliki barang dengan harga yang benar dan sesuai atau memulangkannya. Akan tetapi sekiranya barang tersebut sudah tidak lagi ditangan pembeli, maka dia tidak punya pilihan lain kecuali mengesahkan pembelian tersebut (Ibn Humām, 1970). Walau bagaimanapun penjual diharuskan mengurangkan harga atau perbedaan harga tanpa menghitung barang masih ada ataupun sudah tiada (al-Sharbīnī, 1958). Walaupun semua mazhab menyetujui mengenai prinsip murābahah sebagai satu alat yang sah dan dibernarkan dalam urusan perniagaan, namun mereka berselisih pendapat tentang perincian pelaksanaanya, terutama dari aspek penentuan harga dan kadar keuntungan. Terdapat segolongan ulama dan ahli ekonomi Islam yang mempersoalkan, membantah atau menghindari prinsip murābahah digunakan. Siddiqi (1983), umpamanya, mempersoalkan penggunaan instrumen murābahah oleh institusi keuangan Islam sebagai alat kredit kepada nasabah yang membuat pembelian pembayaran tertangguh yang berarti memberi kesempatan kepada pembiaya mendapatkan keuntungan yang ditentukan diawal tanpa memperhatikan berbagai risiko (Maulidizen, 2018)

Dari aspek penentuan harga, ulama' mazhab Ḥanāfĩ membenarkan penjual menghitung berbagai biaya yang telah dikeluarkan berkaitan dengan barang itu yang menjadi amalan biasa perniagaan, dicampurkan dengan harga perolehan sebagai harga jual (al-Jazīrī, 1985). Mazhab Hanbālī membenarkan semua biaya perbelanjaan yang berkaitan dengan barang itu dimasukan dalam penentuan harga jual dengan syarat setiap unsur perbelanjaan diberitahukan kepada pembeli (al-Jazīrī, 1985). Pendapat mazhab Shāfi'‘̄ serupa dengan mazhab Hanbalī hanya saja mereka lebih menekankan bahwa bayaran yang diperoleh oleh penjual atau bayaran yang dibelanjakan kepada pihak ketiga segala pekerjaan yang dibuat tidak secara sukarela, tidak boleh dimasukan dalam penentuan harga jual kecuali jika pembeli membenarkannya (Borhan, 1998). Sedangkan mazhab Mālikī membagikan biaya perbelanjaan tambahan itu kepada tiga kategori: (1) Semua perbelanjaan yang boleh dicampurkan kepada harga modal yaitu perbelanjaan yang secara langsung berpengaruh kepada barang. Ia menjadi asas kepada pengiraan keuntungan. (2) Perbelanjaan yang boleh dicampurkan dengan harga modal tetapi tidak boleh menjadi asas pengiraan keuntungan yaitu perbelanjaan yang tidak memberikan pengaruh langsung terhadap barang itu, tetapi terpaksa dikeluarkan karena penjual tidak melakukannya sendiri. (3) Perbelanjaan tidak menjadi penentuan harga jual dan asas pengiraan keuntungan yaitu perbelanjaan yang tidak memberikan pengaruh pada barang itu dan ia boleh dilakukan oleh penjual (al-Jazīrīi, 1985).

Dalam konteks sistem keuangan Islam, penggunaan istilah murābahah diperluaskan lagi, yaitu kontrak bay' al- murābahah li al-'Āmir bi al-Syirā'. Diartikan sebagai salah satu perjanjian jual beli antara penjual (biasanya institusi keuangan) dengan nasabah di mana penjual membeli barang yang diperlukan oleh nasabah yang mempunyai keinginan pembiayaan bagi maksud pembelian tersebut. Kemudian Bank akan menjual barang itu kepada nasabah dengan harga yang disepakati, yang memberikan suatu margin keuntungan kepada institusi keuangan, dengan pembayaran akan dibuat oleh nasabah dalam suatu tempo yang disepakati secara sekaligus atau beransur (Qal'ahjī, 1997; Ghani, 1999). Ide mengenai jenis kontrak ini telah diperkenalkan oleh al-Imām al-Shāfí'̄i lebih awal lagi, dan ia baru dikenalkan oleh Sami Hamoud. Adapun ciri utama Bay' al- murābahah li al- 'Ámir bi alSyirā' dan syarat-syaratnya adalah sebagai berikut: (i) Janji yang mengikut pembeli atau nasabah kepada pembiayaan atau Bank untuk membeli barang yang dipesan. Nasabah tidak sah dibebankan dengan tanggung jawab apapun juga kecuali menyempurnakan janjinya setelah ia memiliki barang pesanan tersebut, (ii) Barang pesanan itu harus bagi orang Islam memilikinya dan ia wujud atau akan wujud dalam pasar, (iii) Kontrak jual beli antara Bank dengan penjual pertama yaitu pemilik barang, (iv) kontrak jual 
beli secara murābahah antara Bank dengan nasabah dibuat setelah barang itu benar-benar menjadi milik Bank. Ini karena ia menjadi asas untuk membolehkan Bank mengambil keuntungan. Sekiranya pembayaran dibuat secara angsuran, bank akan menaikkan harga barang karena pembayarannya adalah secara bertangguh (al-Mișrī, 1977). Bank tidak dibenarkan sama sekali menaikkan harga jual atau jumlah bayaran angsuran setelah disetujui pada awal kontrak. Jual beli ini dinamakan dengan Bay' bi alThaman Ajil atau Bay' bi al-Taqsìt (Qal'ahjī, 1997). Perlu dibedakan jangka waktu dengan pelaksanaan perniagaan dengan akad murābahah karena ia melibatkan risiko atau jaminan yang perlu ditanggung oleh Bank sebelum penyerahan barangan kepada nasabah (Hasanīn, 1992).

\subsection{Landasan Hukum Murābahah}

Mayoritas mazhab fiqh menyatakan bahwa murābaḥah disyariatkan (diharuskan) karena ia termasuk pensyariatan jual beli secara umum. Adapun dalil pensyariatan murābaḥah adalah sebagai berikut:

\section{Al-Qur'an}

Kontrak murābahah, sebagaimana dijelaskan di atas, termasuk kontrak jual beli. Allah SWT menegaskan bahwa jual beli dihalalkan, dan ribā diharamkan ((al-Baqarah [2]:275). Ibn al-Humam, seorang Faqih mazhab Hanafì menyatakan bahwa dengan adanya kehalalan kontrak jual beli yang secara tegas disebutkan dalam ayat tersebut, sebenarnya tidak diperlukan adanya dalil lain yang menunjukkan keharusan murābahah. Karena sebenarnya dalil disyariatkannya jual beli secara mutlak 'am, itu juga merupakan dalil keharusan murābahah (Ibn Ḥumām, 1970).

Al-Qur'an memberikan pedoman bahwa sebuah transaksi hanya sah apabila masingmasing pihak yang terlibat dalam transaksi memenuhi kewajiban yang berkaitan dengan konsekuensi sebuah transaksi. Misalnya dalam transaksi yang berbentuk akad jual beli, seorang pembeli harus membayar sejumlah harga yang disepakati, sementara penjual mesti menyerahkan barang yang dijualnya kepada pembeli (al-
Maidah [5]:2). Dan Seseorang yang berjanji, harus memenuhi janjinya (al-Isra [17]:34).

Apa yang dijelaskan dalam ayat tersebut, bahwa penyempurnaan suatu perjanjian merupakan kewajiban penting di sisi Islam. Al-Qur'ān juga menyebutkan bahwa semua transaksi harus dilakukan dalam rangka kerjasama saling menguntungkan (al-Maidah [5]: 2). Dalam ayat lain, Allah SWT memerintahkan untuk menjaga kepercayaan dalam semua transaksi, terutama dalam hal yang berkaitan dengan timbangan (alIsra [17]:35). Setiap transaksi harus dilakukan dengan cara yang benar, saling sukarela dan menghindari cara-cara yang batil (al-Nisa [4]:29). Selain itu dalam transaksi barang yang diperjual belikan harus diakui kehalalanya oleh prinsip Syariah (al-Maidah [5]:4). Allah SWT memberikan peringatan keras terhadap para pelaku transaksi yang melakukan tipuan dan kecurangan (al-Mutaffifin [83]:1-3).

\section{Al-Hadith}

Terdapat beberapa hadis yang menjadi dasar hukum keabsahan murābahah, walaupun tidak menujukkan secara langsung jenis kontrak murābahah, yaitu (i) Hadis yang berkaitan dengan keabsahan dalam melakukan kontrak. Hadis tersebut riwayat al-Bukhārī, Abū Dāwud dan al-Tirmidhī bahawa Nabi Muhammad SAW bersabda yang artinya: "Orang-orang Islam boleh melakukan kontrak dengan membuat apa-apa syarat melainkan syarat yang menghalalkan yang haram dan mengharamkan yang halal" (alTirmidhī, 1967; Ibn Taymiyyah, t.t) (ii) Hadis tentang jual beli secara tangguh. Dari Suhayb alRūmī r.a bahwa Rasulullah SAW bersabda: "Tiga hal yang di dalamnya terdapat keberkatan (yaitu): jual beli secara tangguh, muqāradah (muḍārabah), dan mencampur gandum dengan tepung untuk keperluan rumah, bukan untuk dijual" (Ibn Mājah, 1395). (iii) Hadis tentang etika berhutang. Dari Ibn Abbas r.a bahwa Rasulullah SAW bersabda: "Barangsiapa yang berhutang pada sesuatu, maka hendaklah mengikuti batasan yang tertentu dan timbangan yang tertentu kepada tempo waktu yang tertentu" (alBukhār, t.t). (iv) Dari Abi Sa'id r.a, Rasulullah 
SAW bersabda: "Sesungguhnya jual beli itu mesti dilakukan secara suka sama suka” (alAlbānī, 1986).

\section{Kaedah Fiqh}

Islam adalah agama yang senantiasa sesuai untuk segala zaman dan tempat. Sifat dasar Islam ini didukung oleh instrumen-instrumen hukum yang menjadikanya fleksibel dengan segala perubahan zaman. Diantaranya adalah dalam bidang mu 'āmalah. Para ulama' setelah memahami falsafah yang mendasari hukum Islam, merumuskan suatu kaedah dasar dalam bidang mu'āmalah, yang artinya 'Hukum asal mu'āmalat adalah bahwa segala sesuatunya dibolehkan kecuali ada dalil yang melarang (dalam AlQur'ān dan Al-Hadīîh)" (Al-Suyāṭ̄i, 1399 H). Kaedah ini berdasarkan firman Allah SWT berfirman: "Allah sungguh telah memperinci apa saja yang diharamkan untuk kamu sekalian" (alAn'am [6]:119).

Ini maknanya bahwa segala sesuatu yang haram telah diperincikan secara detail dalam Syariah, sedangkan yang mubah (diharuskan) tidaklah diperinci secara detail dan tidak juga dibatasi secara detail. Oleh karena itu mungkin pada masa mutakhir ini untuk melakukan adopsi terhadap transaksi-transaksi modern yang tidak bertentangan dengan Syariah (al-Nadwī, 1999). Para pihak yang bertransaksi mesti senantiasa menjaga agar transaksi yang dilakukan tidak menimbulkan mudarat bagi dirinya maupun orang lain. Sebagaimana kaedah: "Tidak memudaratkan dan tidak dimudaratkan" (al-Zarqā', 2001).

\section{Fatwa-fatwa Ulama}

Terdapat banyak fatwa ulama yang menunjukkan keharusan murābahah, seperti fatwa penasehat Bayt al-Tamwīl al-Kuwaytī (Syaikh Badr al-Mutawallī 'Abd al-Basīt), ketika ditanya tentang keharusan bank untuk membeli barang secara tunai, kemudian ia menjualnya kepada nasabah yang memintanya dengan harga yang lebih tinggi setelah memperhitungkan biaya operasional. Menurut beliau permintaan nasabah untuk membeli kepada bank merupakan suatu janji. Walau beliau mengakui perbedaan penda- pat para pakar hukum mengenai status wajib atau tidaknya memenuhi janji tersebut, tetapi beliau berpendapat janji tersebut wajib dipenuhi karena selain mendapat dukungan banyak hadis juga menjadikan kemudahan bagi umat manusia. Seminar Keuangan Islam yang pertama di Dubai pada Mei 1979 juga menyatakan bahwa transaksi murābahah mengandungi janji dari pihak institusi keuangan maupun nasabah yang wajib dipenuhi oleh kedua-dua pihak (al-Qaraḍ̄āī, 1987). Syaikh Bin Baz menyatakan bahwa transaksi murābahah adalah diharuskan jika barang yang dijual itu telah benar-benar menjadi milik Bank dan perpindahan hak milik berlangsung secara sah, karena dalil-dalil syar' $i$ yang 'am mengharuskannya.

\subsection{Manfaat dan Resiko Pembiayaan Murābahah}

Transaksi murābahah sesuai dengan sifat perniagaan (tijārah) memiliki beberapa manfaat, demikian juga risiko yang harus dihindarkan. Pembiayaan murābahah memberi banyak manfaat kepada Bank Syariah, salah satunya adalah adanya keuntungan yang muncul dari perbedaan harga beli dari penjual dengan harga jual kepada nasabah. Risiko pembiayaan dapat dikurangkan untuk menghindari kerugian yang lebih besar dengan melakukan berbagai kepatuhan terhadap perundangan yang berlaku. Risiko yang harus dihindari antara lain (Antonio, 2001):

a. Default atau kelalaian; nasabah sengaja tidak membayar angsuran.

b. Turun naik harga secara fruktuatif, ini terjadi apabila harga suatu barang di pasar naik setelah bank membelikannya untuk nasabah. Bank tidak boleh merubah harga jual beli tersebut.

c. Penolakan nasabah, barang yang dikirim bisa ditolak oleh nasabah karena berbagai sebab. Bisa jadi karena rusak dalam perjalanan sehingga nasabah tidak menerima, karena itu perlu dilindungi oleh asuransi. Kemungkinan lain nasabah merasa spesifikasi barang tersebut berbeda dengan yang ia pesan. 


\subsection{Murābahah Dalam Lembaga Keuangan Islam Modern}

Bank-bank Syariah telah berkembang dan mengadopsi berbagai kontrak penjualan Islam untuk membantu pendanaan konsumennya. Kontrak-kontrak tersebut secara mendalam telah dinyatakan dalam Syariah dan dikembangkan melalui sejarah yang panjang oleh para pemikir ekonomi Islam. Salah satunya adalah jual beli murābahah, seperti dipraktekkan oleh Bank Syariah. Namun dalam dunia modern, istilah tersebut sudah merupakan perluasan dari pengertiannya yang klasik. Penerapannya pada institusi keuangan Islam modern adalah nasabah mengajukan pembiayaan dengan system murābahah kepada bank Syariah untuk membelikan barang-barang (produktif dan konsumtif) yang diketahui sifat-sifatnya, di mana nasabah dan bank mengetahui barang tersebut secara nyata dan oleh bank siap untuk mengadakan barang yang dibutuhkan nasabah. Kemudian dibuat suatu akad atau perjanjian antara nasabah dan bank mengenai kesanggupan pihak bank untuk membeli barang yang dikehendaki dan kesanggupan nasabah untuk membeli barang tersebut. Akad ini bukanlah akad jual beli, melainkan akad untuk mengadakan jual beli (Mujahidin, 2016; Anwar, 1995).

Murābahah, sebagaimana yang digunakan dalam perbankan Syariah, prinsipnya didasarkan pada dua elemen pokok, yaitu harga beli serta biaya yang terkait, dan kesepakatan atas mark-up (laba). Bank Syariah mengadopsi murābahah untuk memberikan pembiayaan jangka pendek kepada para nasabah untuk pembelian barang meskipun nasabah tidak memiliki uang untuk membayar. Ciri dasar kontrak murābahah sebagai jual beli dengan pembayaran tertangguh adalah sebagai berikut: (i) si pembeli harus memiliki pengetahuan tentang biaya-biaya terkait dan harga asli barang, dan batas laba (mark-up) harus ditetapkan dalam bentuk persentase dari total harga plus biaya-biayanya; (ii) apa yang dijual adalah barang atau komoditas dan dibayar dengan uang; (iii) apa yang diperjualbelikan harus ada dan dimiliki oleh setiap penjual dan si penjual harus mampu menyerahkan barang itu kepada si pembeli; (iv) pembayarannya ditangguhkan. Murābahah seperti yang dipahami disini, digunakan dalam setiap pembiayaan di mana ada barang yang dapat diidentifikasi untuk dijual (Saed, 2008).

Teknis perbankan Syariah dalam penerapan transaksi murābahah, yaitu; 1) Bank bertindak sebagai penjual sementara nasabah sebagai pembeli. Harga jual adalah harga beli bank dari produsen (pabrik) ditambah keuntungan (markup). Kedua pihak harus menyepakati harga jual dan jangka waktu pembayaran; 2) Harga jual dicantumkan dalam akad jual-beli dan jika telah disepakati tidak dapat berubah selama berlaku akad. Dalam perbankan, murābaḥah lazimnya dilakukan dengan cara pembayaran dicicil; 3) Dalam transaksi ini, bila sudah ada barang diserahkan segera kepada nasabah, sedangkan pembayarannya dilakukan secara tangguh (Sudarsono, 2004)

\subsection{Kritik Pelaksanaan Murābahah Dalam}

\section{Lembaga Keuangan Islam Modern}

Murābahah yang diadopsi oleh bank Syariah adalah sebagai model pembiayaan yang utama dengan portofolio pembiayaannya mencapai 70$80 \%$ jika dibandingkan dengan produk lain yang ditawarkan oleh bank Syariah. Namun dalam praktiknya tak pernah luput dari berbagai macam problem, di antaranya yaitu;

\subsection{Jaminan}

Dalam konteks pemberian pinjaman pada bank konvensional, jaminan memainkan peran penting untuk memastikan pengembalian pinjaman ketika jatuh tempo. Lain halnya dalam konteks hukum Islam (fiqh) bahwa pada dasarnya jaminan bukanlah satu rukun atau syarat yang mutlak dipenuhi dalam murābahah dan jaminan itu bisa saja menjadi penghambatan dalam aliran dana untuk para pengusaha kecil. Pada intinya jaminan itu hanya dimaksudkan untuk menjaga agar nasabah tidak bermain-main dengan pesanannya. Oleh karena itu, bank dapat meminta suatu jaminan untuk dipegangnya. Dalam teknis operasionalnya barang-barang yang dipesan dapat menjadi salah satu jaminan yang 
bisa diterima untuk pembayaran utang (Sudarsono, 2004)

Sebagaimana yang disebutkan di dalam kerangka dasar penyusunan dan penyajian Laporan Keuangan Bank Syariah bahwa bank dapat meminta nasabah menyediakan agunan atas piutang murābahah, antara lain dalam bentuk barang yang telah dibeli dari bank. Selain itu, bank dapat meminta kepada nasabah urbun sebagai uang muka pembelian pada saat akad apabila kedua belah pihak bersepakat. Urbun menjadi bagian pelunasan piutang murābahah apabila murābahah jadi dilaksanakan. Tetapi apabila murābahah batal, urbun dikembaikan kepada nasabah setelah dikurangi kerugian dengan kesepakatan. Jika uang muka itu lebih kecil dari kerugian bank, maka bank dapat menerima tambahan dari nasabah (Indriantoro, dkk., 2002). Meminta jaminan atas utang pada dasarnya bukanlah sesuatu yang tercela. AlQuran memerintahkan umat Islam untuk menulis tanggguhan utang mereka dan jika perlu meminta jaminan atas utang itu. Dalam sejumlah kesempatan, Nabi memberikan jaminannya kepada para krediturnya atas utang beliau. Jaminan adalah salah satu cara untuk memastikan bahwa hak-hak kreditur tidak akan dihilangkan dan untuk menghindarkan diri dari memakan harta orang dengan cara yang batil (Saed, 2008).

\subsection{Tanggungan Risiko}

Diantara kemungkinan risiko yang terjadi dalam kontrak murābahah yang sering menimbulkan problema dan harus diantisipasi, antara lain; 1) Kelalaian, nasabah sengaja tidak membayar ansuran; 2) Fruktuasi harga kompetitif, ini terjadi bila harga suatu barang di pasar naik setelah bank membelikannya untuk nasabah. Bank tidak bisa mengubah harga jual-beli tersebut; 3) penolakan nasabah, barang yang dikirim bisa saja ditolak oleh nasabah karena sebab. Bisa jadi karena rusak dalam perjalanan sehingga nasabah tidak mau menerimanya. Karena itu, sebaiknya dilindungi asuransi. Kemungkinan lain karena nasabah merasa spesifikasi barang tersebut berbeda dengan yang dipesan. Bila bank telah menandatangani kontrak pembelian dengan penjualannya, barang tersebut akan menjadi milik bank. Dengan demikian bank mempunyai risiko untuk menjualnya kepada pihak lain; 4) Dijual, karena murābaḥah bersifat jual-beli dengan utang, maka ketika kontrak ditandatangani, barang itu menjadi milik nasabah. Nasabah bebas melakukan apapun terhadap aset miliknya tersebut, termasuk untuk menjualnya. Jika terjadi demikian, risiko kelalaian akan besar (Maulidizen, 2018).

\subsection{Penundaan Pembayaran Utang}

Jika penundaan pembayaran utang disebabkan faktor-faktor di luar kemampuan nasabah untuk mengontrolnya, bank Syariah secara moral berkewajiban menjadwal ulang utang tersebut. Di lain pihak, jika nasabah secara ekonomi memiliki kemampuan untuk membayar tepat waktu, tetapi ia tidak melakukannya, maka bank Syariah dan dewan pengawasnya telah mengadopsi konsep "denda" untuk dijatuhkan kepada nasabah. Jumlah denda akan tergantung kepada suku laba yang wajar pada bank yang diinvestasikan, yang merupakan biaya untuk menutupi peluang yang hilang (opportunity cost) dari modal. Dalam sebagian kasus, jika pelunasan dari uang muka tidak mungkin, bank akan menyita jaminan untuk menutupi uang muka (Saed, 2008).

Pembiayaan berbasis murabahah harus dilunasi pada jangka waktu tertentu tidak jauh berbeda dengan pembiayaan berbasis bunga. Namun ada perbedaan yang paling mendasar dari kedua pembiayaan tersebut dalam hal debitur gagal melunasi hutang pada waktu yang telah ditentukan. Pinjaman dengan bunga, pada umumnya menimbulkan sanksi bunga tambahan jika pinjaman tidak dilunasi pada saat jatuh tempo. Sedangkan, dalam perbankan Syariah, nasabah harus diberi waktu teloransi untuk melunasi jika ia tidak mampu. Penundaan semacam ini harus diberikan, tanpa menambahkan biaya tambahan kepada nasabah atas waktu yang diberikan untuk pembayaran. Namun bagi nasabah yang mampu melunasinya tetapi mereka 
lalai untuk melunasi hutang tepat waktu, maka Bank Syariah menerapkan konsep "denda".

Semua hal di atas menunjukkan bahwa sampai dalam penyelesaian hutang, Bank Syariah telah menggunakan cara-cara untuk menjamin agar hutang dilunasi tepat waktu, dan jika tidak 'kerugian' yang diperoleh bank ditanggung oleh nasabah. Berdasarkan uraian di atas, maka peran Bank Syariah dalam murabahah sebagaimana dikemukakan oleh Maulidizen, sebagai 'pembiaya' (a financier) bukan 'penjual' barang ( $a$ seller). Bank tidak memegang barang, dan tidak pula mengambil risiko atasnya. Kerja bank hampir semuanya terkait dengan penanganan dokumen-dokumen terkait dan kontrak penjualan adalah sekedar formalitas. Di samping itu, penentuan mark-up dalam kontrak murabahah yang secara bebas ditentukan oleh Bank Syariah, akan dapat memicu munculnya persepsi bahwa mark-up itu identik dengan bunga. Untuk itu, perlu kajian secara dalam tentang konsep pricing dalam murabahah.

\subsection{Bangkrut}

Jika nasabah yang berutang dianggap gagal menyelesaikan utangnya, bank harus menunda tagihan utang sampai nasabah menjadi sanggup kembali membayarnya (Antonio, 2011).

\subsection{Keuntungan Terlalu Tinggi}

Berdasarkan kondisi dan alasan praktik murābahah di bank Syariah, maka ada semacam kecaman atau penilaian masyarakat terhadap praktik bank Syariah tidak jauh berbeda dengan bank konvensional (bank bunga). Dari hasil penelitian yang dilakukan bank Indonesia menunjukkan bahwa $15 \%$ responden menilai bank Syariah tidak ada bedanya dengan bank konvensional, hanya berbeda bungkusnya. Kalangan awam juga menilai bahwa bank Syariah dalam mengambil keuntungan lebih besar dari bank konvensional, karena selama ini kalangan awam menilai bahwa lembaga keuangan Syariah selalu identik dengan harga murah, sehingga jika terjadi penjualan barang oleh bank Syariah dengan harga yang lebih tinggi dibandingkan dengan harga jual bank konvensional, maka bank Syariah dinilai lebih tidak
Islami. Hal seperti demikian sangat mungkin terjadi, oleh karena itu, perlu kiranya dicarikan kemasan produk murābahah yang memberikan keuntungan secara adil antara pihak bank dengan nasabah.

Dalam praktiknya, tinggi margin keuntungan yang diambil oleh pihak bank adalah untuk mengantisipasi naiknya suku bunga di pasar atau inflasi, sehingga kalau terjadi kenaikan suku bunga yang besar, maka bank Syariah tidak mengalami kerugian secara riil, namun jika suku bunga di pasar tetap stabil atau bahkan turun, margin murābahah akan lebih besar dibanding dengan tingkat bunga pada bank konvensional (Muhammad, 2005). Permintaan untuk pembelian oleh nasabah dilengkapi dengan suatu janji untuk membeli yang disertai dengan pembayaran uang muka untuk menjamin bahwa nasabah memang serius dalam permintaan pembeliannya dan bahwa ia akan menyelesaikan pembayarannya ketika bank menunjukkan kesiapan untuk menyelesaikan kontrak jual beli murābahah begitu bank mengabarkan bahwa barang telah siap diserahkan atau dokumen-dokumen berkenaan dengan barang telah tiba. Kontrak penjualan akan segera diselesaikan setelah bank diberitahu oleh suplier bahwa barang telah siap dikirim. Bank tidak perlu menunggu tibanya barang untuk diperiksa sebelum diserahkan kepada pembeli. Jika ada cacat dalam penanganan, maka cacatnya ditangani oleh perusahaan asuransi, yang biaya asuransinya telah dimasukkan ke dalam total harga barang dan oleh karenanya ditanggung oleh pembeli. Kurir pengantar barang dianggap sebagai wakil bank dalam kaitannya dengan barang, maka pembeli dapat menyelesaikan semua masalah pengiriman dengan kurir tersebut, tanpa berurusan dengan bank (Saed, 2008).

\subsection{Konsep Pricing Dalam Pembiayaan Murabahah: Sebuah Alternatif}

Sebagaimana telah dikemukakan di atas bahwa kritik terhadap pembiayaan murabahah yang banyak diberikan oleh para Ilmuwan Islam adalah tidak ada perbedaan yang mendasar antara mark-up dalam kontrak murabahah di Bank Syariah dengan bunga dalam pinjaman kredit di 
bank konvensional. Oleh karena itu, Bank Syariah perlu menetapkan metode yang tepat dan efisien agar pembiayaan murabahah dapat memberikan keuntungan secara adil antara pihak Bank Syariah dengan nasabah.

Pembiayaan murabahah merupakan salah satu bentuk natural Certainty Contract, karena dalam murabahah ditentukan berapa required rate of profit. Natural Certanty Contract merupakan kontrak dalam bisnis yang memberikan kepastian pembiayaan, baik dari segi jumlah (amount) maupun waktu (timing). Cash flow dapat diprediksi dengan relatif pasti karena sudah disepakati oleh kedua belah pihak yang bertransaksi di awal akaad. Kontrak ini menawarkan return yang tetap dan pasti. Objek pertukarannya, biasanya berupa barang, harus ditetapkan di awal akad dengan pasti baik jumlah (Quantity), mutu (quality), harga (price) dan waktu penyerahnnya (time of delivery). Produk perbankan Syariah yang termasuk dalam kategori ini adalah pembiayaan murabahah dan ijarah (Karim, 2004). Penentuan harga pada sebuah kontrak yang menghasilkan keuntungan pasti (natural certanty contract), pada kebanyakan perusahaan atau bank, biasanya menggunakan salah satu dari metode (Muhammad, 2005).

\subsection{Mark-up Pricing}

Metode mark-up pricing adalah penentuan tingkat harga dengan menambah biaya produksi (product's cost) komoditas yang bersangkutan. Pada metode ini, sebuah perusahaan atau bank akan menjual produknya pada tingkat harga biaya produksi ditambah mark-up atau margin yang diinginkan

\subsection{Target Return Pricing}

Target Return pricing merupakan penentuan harga jual produk yang bertujuan mendapatkan return atas besarnya modal yang diinvestasikan, dalam bahasa keuangan dikenal dengan istilah return on Investmen (ROI). Dalam hal ini, perusahaan atau bank akan menentukan berapa return yang diharapkan atas modal yang diinvestasikan.

\subsection{Perceived Value Pricing}

Berbeda dengan metode target return pricing yang hanya menggunakan biaya produksi sebagai kunci penentuan harga, pada preceived value pricing juga menggunakan non-price variable sebagai dasar penentuan harga jual. Dalam metode perceived value pricing, penentuan harga dengan tidak menggunakan variable harga sebagai dasar harga jual. Harga jual didasarkan pada harga produk pesaing dimana perusahaan atau bank melakukan penambahan atau perbaikan unit untuk meningkatkan tingkat kepuasan customer. Dengan demikian, perusahaan atau bank dapat menentukan harga dengan mempertimbangkan tingkat kepuasan customer terhadap suatu komoditi yag dikonsumsi.

\subsection{Value Pricing}

Adalah suatu kebijakan harga yang kompetitif atas barang yang berkualitas tinggi. Sebagaimana disebutkan dalam pepatah jawa "Ono rego ono ruppo". Hal ini sudah menjadi pemahaman umum bahwa barang yang baik, harganya mahal. Namun perusahaan yang sukses adalah perusahaan yang mampu menghasilkan barang yang berkualitas dengan biaya yang efisien sehingga perusahaan tersebut dapat dengan leluasa menentukan tingkat harga di bawah harga competitor.

Penentuan harga dalam pembiayaan murabahah di lembaga keuangan Islam modern dapat menggunakan salah satu di antara empat model di atas. Namun, penentuan harga jual produk-produk Bank Syariah harus tetap memperhatikan ketentuan-ketentuan yang dibenarkan oleh Syariah. Oleh karena itu, Bank Syariah perlu menetapkan metode yang tepat dan efisien agar pembiayaan murabahah dapat memberikan keuntungan yang adil antara pihak Bank Syariah dengan nasabah.

Jika Bank Syariah hendak menerapkan metode mark-up pricing, maka metode ini hanya tepat jika digunakan untuk pembiayaan yang sumber dananya dari Restricted Investment Account (RIA) atau Mudarabah Muqayyadah. Oleh karena itu, metode mark-up pricing tidak tepat untuk digunakan dalam pembiayaan 
murabahah. Oleh karena itu Bank Syariah dapat menerapkan matode target return pricing untuk pembiayaan murabahah. Karena pembiayaan murabahah dilakukan dengan akad natural certainty contract, maka metode yang digunakan adalah required profit rate (rpr). Dalam hal ini tinggi rendahnya $r p r$ dipengaruhi oleh tingkat keuntungan setiap satu transaksi dan besarnya jumlah transaksi dalam suatu periode. Namun perlu dicatat, bahwa dua variabel tersebut, yaitu tingkat keuntungan dan besarnya jumlah transaksi, hanyalah variable independet saja, sedangkan yang menentukan tingkat keuntungan yang sesungguhnya seringkali dipengaruhi oleh faktor lain, seperti tingkat harga pasar (biasanya bank juga menjadikan suku bunga sebagai benchmark (rujukan) dalam penentuan tingkat keuntungan yang diinginkan). Penentuan nilai $r p r$ dapat dihitung dengan menggunakan pendekatan sebagai berikut:

Keterangan:

$$
r p r=n . v
$$

$\mathrm{n}=$ tingkat keuntungan dalam transaksi tunai

$\mathrm{v}=$ jumlah transaksi dalam satu periode

Para praktisi perbankan Syariah perlu berhati-hati dalam penerapan metode $r p r$ di Bank Syariah. Karena lazimnya, Bank Syariah juga menggunakan tingkat suku bunga pasar sebagai benchmark. Bank Syariah harus tidak hanya menjadikan tingkat suku bunga sebagai rujukan dalam penentuan harga jual (pokok + margin). Cara penetapan margin yang hanya mengacu pada tingkat suku bunga sebagai benchmark merupakan langkah sesat sekaligus menyesatkan dan lebih berat lagi dapat merusak reputasi Bank Syariah.

Dalam prakteknya, barangkali tingginya profit margin yang diambil oleh Bank Syariah adalah untuk mengantisipasi naiknya suku bunga di pasar (inflasi). Sehingga kalau terjadi kenaikan suku bunga yang besar, maka Bank Syariah tidak mengalami kerugian secara riil. Namun demikian, apabila suku bunga di pasar tetap stabil atau bahkan turun, maka margin murabahah akan lebih besar dibandingkan denga tingkat bunga pada bank konvensional. Dengan penetapan profit margin murabahah yang tinggi, secara tidak langsung bahkan akan menyebabkan inflasi lebih besar daripada yang disebabkan oleh bunga. Oleh karena itu, perlu dicari format yang tepat agar nilai penjualan dengan murabahah tidak mengacu pada sikap mengantisipasi kenaikan suku bunga selama masa pembayaran ansuran. Karena, mengkaitkan profit margin murabahah dengan bunga bank konvensional, tetaplah bukan cara yang baik (Muhammad, 2005)

Penetapan harga jual murabahah, sebaiknya dapat dilakukan denga cara Rasulullah SAW ketika berdagang. Cara ini dapat dipakai sebagai salah satu metode Bank Syariah dalam menentukan harga jual produk murabahah. Cara Rasulullah SAW dalam menentukan harga penjualan adalah menjelaskan harga belinya, berapa wajar yang diinginkan. Ara penetapan harga jual tersebut berdasarkan cost plus markup (Wiyono, 2005). Secara matematis, menurut Muhammad, harga jual murabahah dengan metode cost plus mark-up dapat dihitung dengan rumusan sebagai berikut:

$$
\begin{aligned}
\text { Harga Jual }= & \text { Harga Beli }+ \text { Cost Recovery } \\
& + \text { Keuntungan }
\end{aligned}
$$

Cost Recovery $=\frac{\text { Estimasi Biaya Operasi }}{\text { Target Volume Pembiayaan }}$ Margin $=\frac{\text { Cost Recovery }+ \text { Keuntunganx } 100 \%}{\text { Harga Beli }}$

Cost recovery adalah bagian dari estimasi biaya operasi Bank Syariah yang dibebankan kepada harga beli/ total pembiayaan. Cost recovery tersebut bisa didekati dengan membagi estimasi biaya operasi dengan target volume pembiayaan murabahah, kemudian ditambahkan dengan harga beli dari suplier dan keuntungan yang diinginkan sehingga didapatkan harga jual. Sedangkan margin murabahah didapat dari cost recovery ditambah keuntungan dibagi dengan harga beli. 
Persentase margin di atas dapat dibandingkan dengan suku bunga. Jadi, suku bungan hanya dijadikan sebagai benchmark. Agar pembiayaan murabahah lebih kompetitif, margin murabahah tersebut harus lebih kecil dari bunga pinjaman. Jika masih lebih besar, maka yang harus dimainkan adalah dengan memperkecil cost recovery dan keuntungan yang diharapkan (Muhammad, 2005). Dengan metode ini, diharapkan keuntungan Bank Syariah akan meningkatkan meskipun dengan profit margin yang lebih kecil jika dibandingkan dengan bunga pinjaman bank konvensional. Hal lain yang perlu dicatat bahwa hasil perhitungan margin yang dicantumkan dalam pembiayaan murabahah dinyatakan dalam rangka nominal, bukan bentuk persentasenya.

\section{Kesimpulan}

Dari seluruh pembahasan di atas, dapat disimpulkan dari artikel ini, yaitu; murābahahah wajib menjadi salah satu Al-Qur'an, al-Hadits dan Ijma 'Ulama', meskipun tidak ada ayat AlQur'an atau tradisi Nabi yang langsung menjelaskan murābahah, tetapi ada pedoman umum tentang perdagangan, keuntungan, kerugian dan perdagangan. Singkatnya, murābahah didefinisikan sebagai penjualan barang dan harga disepakati oleh kedua pihak yang mengadakan kontrak. Murābahah adalah salah satu kontrak jual beli yang disahkan. Oleh karena itu, syarat dan prinsip murabahah adalah: penjual dan pembeli, kontrak șīgah, barang (ma'qud 'alayh) dan harga (al-thaman), ditambah beberapa kondisi khusus. Dan tawaran konsep harga dalam pembiayaan murabahah diharapkan dapat mencerminkan nilai Syariah dalam lembaga keuangan Islam modern. Karena kehadiran perbankan syariah di tengah-tengah masyarakat diharapkan dapat menyelesaikan semua masalah ekonomi rakyat. Perlu ada peningkatan dalam pelaksanaan murabah, sehingga dapat memperbaiki segala kekurangan yang ada dan menarik orang untuk menggunakan jasa keuangan. Tawaran konsep pricing dalam pembiayaan murabahah diharapkan dapat mencerminkan nilai Syariah dalam lembaga keuangan Islam modern. Oleh karena hadirnya Bank Syariah di tengah-tengah masyarakat diharapkan mampu memecahkan segala problem ekonomi umat. Perlu ada perbaikan dalam pelaksanaan murabahah, sehingga dapat memperbaiki segala kekurangan yang ada dan menarik minat masyarakat untuk menggunakan jasa keuangan

\section{Ucapan Terimakasih}

Terima kasih diucapkan kepada seluruh pihak yang telah membantu dalam penulisan artikel ini. Khususnya dalam pengumpulan bukubuku, artikel dan dokumentasi yang berkaitan dengan pembiayaan murābahah.

\section{Daftar Pustaka}

Al-Albān̄̄, Muhạmmad Nāsi al-Dīn. (1986). Sahīh al-Jāmī al-Saghīr wa Ziyādatuh. Juz 1. Cet. 2. Beirut: 1-Maktab al-Islāmī.

Al-Ashqar, Muhammad Sulaimān et al. (1998). Buhūth Fiqhiyyah fi Qad̄āyā Iqtiṣādiyyah Mu'āsirah. Juz. 1. 'Amman: Dār al-Nafă' is.

Al-Bukhārī Muḥammad Ibn Ismā'īl. ȘaḥihhalBukhārī. Juz 3. Kaherah: Dār al-Hadīth.

Al-Dasūqī, Syams al-Dīn al-Syaikh Muhammad (t.t.). Hāsyyiyah al-Dasūqū 'alā al-Syarh alKabīr. Juz 4. Beirut: Dār al-Fikr.

Al-Fīyrūzābādī. (1983). al-Qāmūs al-Muhìt. Juz 1. Beirūt: Dār al-Fikr.

Al-Jazīrī, 'Abd al-Raḥmān (1985). Kitab al-Fiqh 'alā al-Madhāhīb al-'Arba'ah. Ed. 6. Jil. 2. Kaherah: al-Maktabah al-Tijāriyyah alKubrā.

Al-Kāsānī, Al- Imām 'Alā al-Dīn Abī Abu Bakr Ibn Mas'ūd (t.t). Badā' 'i al-Sanā' $i$ ' fì Tartīb al-Syarā'i'. Juz 5. Beirut: Mațba'ah al'Āṣimah.

Al-Miṣrī, Rafiq Yūnus. (1977). Mașraf alTanmiyat al-Islāmī. Beirut: Mu'assasah alRisālah

Al-Nadwī' 'Alī Aḥmad. (1999) Mausū'ah alQawā'id wa al-Dawābit al-Fiqhiyyah. Beirut: Dār 'Ālam al-Ma'rifah.

Al-Nawawī, Abū Zakariyyā Muhyi al-Dīn bin Sharaf (t.t). Rawdah al-Ṭālibīn. Al-Maktab al-Islāmī li al-Tabā' wa al-Nasyr. 
Al-Shāfi‘̄i, Muḥammad bin Idrīs. (1968). alUmm. Kaherah: Dār al-Sya'b.

Al-Sharbīn̄i, Muhammad al-Khațīb. (1958). Mughnī al-Muhtāj. Juz 2. Kaherah: Syarikah Maktabah wa Maṭba'ah al-Muștafā al-Bābī al-Ḥalabī wa Awlādih.

Al-Suyāṭī, Al-Imām Jalāl al-Dīn 'Abd. alRaḥmān. (1399 H) Al-Asybāh wa al-Nāza'īr. Cet. 1. Beirut: Dār al-Kutub al-'Ilmiyyah.

al-Tanūkhi, Șaḥnūn 'Abd al-Salām Ibn Sa'īd Habīb (t.t). Al-Mudawwamah al-Kubrā. Jil. 3. Beirut: Dār Șadīr.

Al-Tirmidhī, Muhammad Ibn 'Īsā. (1967). Sunan al-Tirmidhī (al-Jāmī al-Șah̄ịh). Juz 3. Kaherah: Maktabah al-Bābī al-Ma'rifah alHalabī.

Al-Zarqā, al-Syaikh Muḥammad. (2001). Syarh al-Qawā'id al-Fiqhiyyah. Cet. 6. Dimasyq: Dār al-Qalam.

Al-Zarqā, Mușṭafa Aḥmad. (1968). al-Madkhal al-Fiqhī al-'Ām. Jil 1. Damsyiq: t.p.

Antonio, Muhammad Syafi'i. (2011). Bank Islam dari Teori ke Praktek. Jakarta: Gema Insani Press.

Anwar, S. (1995). Permasalahan Produk Bank Syariah, Studi tentang Bai' Muajjal. Yogyakarta: Balai Penelitian P3M IAIN Sunan Kalijaga Yoryakarta.

Borhan, J. T. (1998). Bay 'al-Murabahah in Islamic Commercial Law. Jurnal Syariah API UM, 53-58.

Borhan, J. T. (2001). Falsafah Ekonomi dan Instrumen Muamalah dalam Amalan Perbankan Islam di Malaysia. Jurnal Usuluddin, 13, 115-140.

Burhanuddin, S. (2010). Aspek Hukum Lembaga Kewangan Syariah. Yogyakarta: Graha Ilmu.

Ghani, Ab Mu'min Ab. (1999). Sistem Kewangan Islam dan Pelaksanaanya di Malaysia. Kuala Lumpur: JAKIM.

Hamoud, S. (1985). Islamic Banking. London: Arabian Information Ltd.

Haron, S. (1996). Prinsip dan Operasi Perbankan Islam. Kuala Lumpur: Berita Publishing Sdn Bhd.

Hasan̄in, Fayyā 'Abd al-Mun'īm. (1992). bay' al-Murābahah fì al-Mașārif al-Islāmīyyah.
Kaherah: al-Ma'had al-Ālami li al-Fikr alIslāmī.

Ibn al-Ḥumām, Al-Imām Kamāl al-Dīn 'Abd alRāḥid al-Sirāsi. (1970). Sharh Fatḥ al-Qadīr. Jil. 5. Beirut: Dār al-Kutub al-'Ilmiyyah.

Ibn Mājah, Muhammad Ibn Yāzīd. (1395 H). Sunan Ibn Mājah. Juz 2. Beirut: Dār Ihyēà' al-Turāth al-'Arabī.

Ibn Manẓūr, Abū al-Faḍl Jamāl al-Dīn Muhammad Ibn Mukarram. (1954). Lisān al- 'Arab. Jil. 4 Kaherah: al-Dār al-Mișriyyah li al-Ta' líf wa al-Tarjamah.

Ibn Qudāmah, 'Abd Allāh Ibn Aḥmad alMaqdisī. (1972). Al-Mughnī Wa al-Sarh alKabīr. Juz 4. Beirut: Dār al-Kutub al-'Arabī.

Ibn Rushd, Muhammad Ibn Ahmad Ibn Muhammad. (1988). Bidāyah al-Mujtahid wa Nihāyah al-Muqtașid. Juz. 2. Beirut: Dār al-Qalam.

Ibn Taymiyyah (t.t). Nazariyyah al-'Aqd. Beirut: Dār al-Ma'rifah.

Indriantoro, N. dkk. (2002). Kerangka Dasar Penyusunan dan Penyajian Laporan Keuangan Bank Syariah, Cet. I. Jakarta: Dewan Standar Akuntansi Keuangan Ikatan Akuntan Indonesia.

Kamri, N. A. dan Mansor, F. (2002). Aplikasi Konsep al- murābahah dalam Penawaran Instrumen di Institusi Perbankan Islam di Malaysia, Prosiding Seminar Kewangan Islam, APIUM, Kuala Lumpur, p. 126.

Karim, A. (2004). Bank Islam (Analisis Fiqih dan Kewangan. Jakarta: PT. Raja Grafindo Persada.

Karim, A. (2004). Sejarah Pemikiran Ekonomi Islam. Jakarta: PT.Raja Grafindo Persada.

Maulidizen, A. (2017). Islamic Finance In Theory And Practice: A Critical Analysis. Jurnal IslamiConomics. Vol. 8 (2): 111-140

Maulidizen, A. (2018). A Critical Analysis of Islam, Economy, and Finance In The Early $21^{\text {st }}$ Century. Jurnal Hukum Islam Vol. XVI (2): 132-151

Muhammad. (2000). Sistem \& Prosedur Operasional Bank Syariah. Yogyakarta: UII Press. 
Muhammad. (2005). Manajemen Pembiayaan Bank Syariah. Yoyakarta: Unit Penerbit dan Percetakan AMP YKPN.

Mujahidin, A. (2016). Hukum Perbankan Syariah. Jakarta: Rajawali Press.

Musjtari, Dewi Nurul. (2000). Penyelesaian Sengketa Operasional Bank Syariah. Yogyakarta: Nuha Medika.

Nasution, H. (1986). Akal dan Wahyu dalam Islam. Jakarta: UI Press

Qal'ahjī, Muhammad Rawwās. (1997). Mabāhith fì al-Iqtiṣād al-Islāmī. Beirut: Dār al-Nafā'is.

Qaraḍāwī, Yūsuf. (1987). bay' al-murābahah li al-'Amir bi al-Syirā' kama Tajrīhī alMașārif al-Islāmiyyah. Maktabah Wahbah.

Saed, A. (1996) Islamic Banking and Interest: A Study of The Prohibition of Riba and Its Contemporary Interpretation. Leiden: E.J Brill.

Saed, A. (2008). Bank Islam dan Bunga. Yogyakarta: Pustaka Pelajar.

Sholihuddin, Muhammad. (2011) Kamus Istilah Ekonomi, Keuangan dan Bisnis Syariah. Jakarta: PT. Gramedia Pustaka Utama.
Shubair, Muḥammad 'Uthmān. (1998). alMu'àmalat al-Māliyyah al-Mu'āșirah fì alFiqh al-Islāmī. Beirut: Dāl al-Nafā'is.

Siddiqi, M. N. (1983). Issues in Islamic banking. Islamec Fundation.

Sudarsono, H. (2004). Bank dan Lembaga Keuangan Syariah, Deskripsi dan Ilustrasi. Cet. I. Edisi II. Yogyakarta: Ekoisia.

Sutedi, A. (2009). Perbankan Syariah Tinjauan dan Beberapa Segi Hukum. Bogor: Ghalia Indonesia.

Tabari, N. M. (2010). Islamic Finance and The Modern World: The Legal Principles Governing Islamic Finance in International Trade, Journal Company Law, Comp. Law. Vol. 31 (8), p. 249-254.

Usmani, Muhammad Taqi. (2002). An Introduction to Islamic Finance. London: Kluwer Law International.

Waḥbah, Al-Zuhailī. (1989). al-Fiqh al-Istāmī wa 'Adillatuh. Juz 3. Beirut: Dār al-Fikr. 